\title{
Convergent Effects of Lithium and Valproate on the Expression of Proteins Associated with Large Dense Core Vesicles in NGF-differentiated PCI 2 Cells
}

\author{
Mara L Cordeiro', Cameron B Gundersen' and Joy A Umbach*,' \\ 'Department of Molecular and Medical Pharmacology and Crump Institute for Molecular Imaging, UCLA, School of Medicine, Los Angeles, CA, \\ USA
}

\begin{abstract}
Lithium and valproate are chemically unrelated compounds that are used to treat manic-depressive illness. Previously, we reported that lithium ions upregulate genes encoding proteins primarily associated with large dense core vesicles (LDCV) in nerve growth factor (NGF)-differentiated $\mathrm{PCl} 2$ cells, but not in undifferentiated $\mathrm{PCI} 2$ cells. Moreover, lithium did not alter the expression of proteins associated with small-clear, synaptic-like vesicles (SSV) in these cells. Based on these observations, we investigated whether valproate had actions similar to those of lithium in PCI 2 cells. Thus, undifferentiated or NGF-differentiated PCI 2 cells were exposed to lithium (I mM) or valproate $(\mathrm{I} \mathrm{mM})$ for $48 \mathrm{~h}$. Extracts from these cells were submitted to semiquantitative Northern and Western analyses. In NGFdifferentiated cells, both agents increased the expression of proteins associated with LDCV, the vesicular monoamine transporter I (VMATI), and cysteine string protein (CSP). These same treatments did not alter the expression of proteins primarily associated with SSV, the vesicular acetylcholine transporter (VAChT), and synaptophysin (SY). Furthermore, neither drug affected the expression of these proteins in undifferentiated cells. Interestingly, secretion of ${ }^{3} \mathrm{H}$-dopamine was increased in cells exhibiting the increase of VMATI and csp. Taken together, the convergent effects of these chemically diverse compounds suggest that altered dynamics of LDCV may play a vital role in the biochemical pathway, leading to the relief of the symptoms of manic depression.

Neuropsychopharmacology (2004) 29, 39-44, advance online publication, 03 September 2003; doi: I 0.1038/sj.npp. I 300288
\end{abstract}

Keywords: vesicular monoamine transporter; cysteine string proteins; lithium; valproate; large dense core vesicles

\section{INTRODUCTION}

Manic-depressive disorders produce debilitating psychiatric symptoms in approximately $1 \%$ of the population (Goodwin and Jamison, 1990). Numerous agents have been shown to be clinically useful in managing manic-depressive disorders (McElroy and Keck, 2000; Nemeroff, 2000). Among these drugs, lithium, a monovalent cation, has been a first-line treatment (Schou, 1997; Compton and Nemeroff, 2000). More recently, agents that were originally recognized for their anticonvulsant properties, including valproate (a monocarboxylic acid), have exhibited efficacy in controlling manic-depressive symptoms (McElroy and Keck, 2000; Nemeroff, 2000). The fact that compounds that are as chemically distinct as lithium and valproate display a

\footnotetext{
*Correspondence: Dr JA Umbach, Department of Molecular and Medical Pharmacology, Crump Institute for Molecular Imaging 1220, Los Angeles, CA 90095-1770, USA, Tel.: + I 310825 2973, Fax: + I 310206 8975, E-mail: jumbach@mednet.ucla.edu

Received 04 December 2002; revised 10 July 2003; accepted I5 July 2003

Online publication: 21 July 2003 at http://www.acnp.org/citations/ NPP072 $10302445 /$ default.pdf
}

similar mitigating effect in this disorder has prompted efforts to determine whether these drugs act via overlapping biochemical pathways. Numerous examples of common actions of these agents have emerged. For instance, lithium and valproate enhance AP-1 DNA-binding activity in cultured cells and rat brain (Ozaki and Chuang, 1997; Chen et al, 1999), and they modulate the expression of genes regulated by AP-1, including tyrosine hydroxylase (Chen et al, 1998; Zigova et al, 1999; Sands et al, 2000) and c-Jun (Yuan et al, 1998, 1999). Lithium and valproate also downregulate the myristoylated alanine-rich $\mathrm{C}$ kinase substrate (Lenox et al, 1996; Watson et al, 1998). More recently, it was reported that lithium and valproate influence the stability of neuronal growth cones, and this effect is suppressed by inhibitors of prolyl oligopeptidase (Williams et al, 2002). A theme in all of these investigations is that common cellular and molecular actions of these drugs may give insights into the pathways by which they exert therapeutic effects in bipolar disorders.

Recently, we reported that lithium alters the expression of several proteins (eg cysteine string protein (CSP) and VMAT1) involved in neurosecretory pathways (Cordeiro et al, 2000a,b). Specifically, we found that proteins 
associated principally with large dense core vesicles (LDCV) of PC12 cells were upregulated by lithium (Cordeiro et al, 2000b). In contrast to the small-clear, synaptic-like vesicles (SSV), which predominantly contain acetylcholine, LDCV are the sites of storage of neuropeptides and catecholamines in PC12 cells (Liu et al, 1994; Liu and Edwards, 1997). This preferential effect of lithium on the expression of LDCV proteins (compared to SSV) may be of therapeutic relevance, and the current investigation was undertaken to assess whether valproate, like lithium, exhibits this selective effect on the expression of LDCV proteins.

\section{METHODS}

\section{Cell Culture and Drug Treatment}

PC12 cells were cultured on collagen-coated plates and differentiated using NGF $2.5 \mathrm{~S}$ ( $50 \mathrm{ng} / \mathrm{ml}$; Alomone Labs, Jerusalem, Israel) for 10-18 days as described (Cordeiro et al, 2000a, b). After differentiation by NGF, cells were typically treated either with $1 \mathrm{mM} \mathrm{LiCl}$ or sodium valproate (at the concentrations indicated) for $48 \mathrm{~h}$. This time was chosen because previous results indicated that lithium induced significant changes of CSP within this time frame (Cordeiro et al, 2000a), and pilot experiments revealed that exposure of differentiated PC-12 cells to valproate $(1 \mathrm{mM})$ led to increased CSP immunoreactivity at $16 \mathrm{~h}$ with a plateau between 24 and $48 \mathrm{~h}$. For studies of $\left[{ }^{3} \mathrm{H}\right]$-dopamine $\left(\left[{ }^{3} \mathrm{H}\right]-\mathrm{DA}\right)$ secretion, $4000 \mathrm{PC} 12$ cells were plated on $35 \mathrm{~mm}$ collagen-coated plates (Biocoat Collagen I, Becton Dickinson, Bedford, MA) and differentiated with NGF, as above.

\section{Northern Blot Analysis}

Total RNA was isolated and resolved electrophoretically for Northern analysis using high-stringency conditions as described previously (Cordeiro et al, 2000a, b). Probes for CSP, SY, and VMAT1 were as described (Cordeiro et al, 2000a, b). Quantitative analysis of VAChT mRNA was not performed, due to the very low abundance of VAChT mRNA (however, effects of drug treatments on VAChT were assessed by immunoblot). Binding of probe for CSP $(5 \mathrm{~kb})$, SY $(2.4 \mathrm{~kb})$, and VMAT1 $(3 \mathrm{~kb})$ was detected and quantified by phosphorimager analysis (Image Reader V1.2 Mac-BAS 5000; Fuji, Japan). Densitometric signals for drug-treated cells were normalized to those for untreated cells, and the results are reported as mean \pm SEM values of three to four independent experiments. Student's $t$-test was used to assess significance.

\section{Immunoblot Analysis}

Undifferentiated and NGF-differentiated cells were washed with cold, phosphate-buffered saline, scraped off the plate, centrifuged at $3000 \mathrm{~g}$ for $5 \mathrm{~min}$, and either lysed immediately or stored at $-70^{\circ} \mathrm{C}$. Cells were extracted by sonicating for $20 \mathrm{~min}$ in lysis buffer $(150 \mathrm{mM} \mathrm{NaCl}, 50 \mathrm{mM}$ Tris-HCl pH 7.4, 1\% SDS, and 1\% CHAPS), followed by solubilization at $4^{\circ} \mathrm{C}$ for $1 \mathrm{~h}$. The detergent was removed from a sample of cell lysate (Wessel and Flugge, 1984), and assayed for protein by the Bradford method (Bradford, 1976). Immunoblotting was performed after determining the linear range of detection for CSP $(35 \mathrm{kDa})$, VAChT $(70-75 \mathrm{kDa})$, SY $(38 \mathrm{kDa})$, SNAP-25 $(25 \mathrm{kDa})$, and VMAT1 $(70-75 \mathrm{kDa})$ in PC12 cell extracts. For CSP analysis, $0.5 \mu \mathrm{g}$ PC12 cell protein was resolved electrophoretically, as previously described (Cordeiro et al, 2000a). The same gels probed for CSP immunoreactivity were subsequently probed for SNAP-25 immunoreactivity. Since we previously (Cordeiro et al, 2000a) determined that lithium (at $1 \mathrm{mM}$ ) did not alter the expression of SNAP-25, we were interested whether SNAP25 expression was affected by valproate. For VMAT1 and VAChT, $80 \mu \mathrm{g}$ of PC12 cell protein was resolved on an $8.5 \%$ gel, while for SY, $40 \mu \mathrm{g}$ of protein was loaded on a $12.5 \%$ gel. Conditions for gel electrophoresis, transfer of protein to nitrocellulose, and immunoblot detection were described previously (Cordeiro et al, 2000a). VMAT1 and VAChT antibodies were purchased from Chemicon International (Temecula, CA), and used at a final concentration of $10 \mu \mathrm{g} /$ ml. SNAP-25 antibody was purchased from Alomone Labs (Jerusalem, Israel) and used at $1.6 \mu \mathrm{g} / \mathrm{ml}$. Densitometric analysis of immunoblots yielded results that were compared between control and drug treated cells. Data are reported as mean \pm SEM. Student's $t$-test was used to assess the significance of four to seven independent experiments, and $p<0.05$ was used as the criterion for the significance of differences between the means.

\section{$\left[{ }^{3} \mathrm{H}\right]-D A$ Release Assay}

Evoked release experiments were performed essentially as described by Greene and Rein (1977), with these modifications: uptake of $\left[{ }^{3} \mathrm{H}\right]-\mathrm{DA}$ was performed at $37^{\circ} \mathrm{C}$ in culture medium with $1.5 \mu \mathrm{Ci} / \mathrm{ml}\left[{ }^{3} \mathrm{H}\right]-\mathrm{DA}, 0.5 \mathrm{mM}$ L-ascorbic acid (Sigma), and $1.0 \mu \mathrm{M}$ DA. After $90 \mathrm{~min}$, the cells were washed with HEPES-buffered saline containing calcium and magnesium (HBS-CM: $150 \mathrm{mM} \mathrm{NaCl}, 10 \mathrm{mM}$ HEPES, $2 \mathrm{mM}$ $\mathrm{CaCl}_{2}, 0.8 \mathrm{mM} \mathrm{MgCl}_{2}$ ), and incubation was continued for $30-60 \mathrm{~min}$ at $37^{\circ} \mathrm{C}$ in culture medium containing NGF (and lithium or valproate where appropriate). All solutions were freshly prepared on the day of the experiment, and prewarmed at $37^{\circ} \mathrm{C}$. Cells were preincubated in $1.5 \mathrm{ml}$ low potassium $\left(\mathrm{K}^{+}\right)$solution $(125 \mathrm{mM} \mathrm{NaCl}, 4.8 \mathrm{mM} \mathrm{KCl}$, $2.6 \mathrm{mM} \mathrm{CaCl}, 1.2 \mathrm{mM} \mathrm{MgSO}$, $5.6 \mathrm{mM}$ glucose, $25 \mathrm{mM}$ HEPES, $1.0 \mathrm{mM}$ ascorbic acid, 3\% normal horse serum (NHS), $\mathrm{pH} 7.3$ ) for $5 \mathrm{~min}$ at $37^{\circ} \mathrm{C}$. This preincubation solution was replaced with low $\mathrm{K}^{+}$solution for $30 \mathrm{~s}$. This low $\mathrm{K}^{+}$solution was collected for liquid scintillation spectrometry, and cells were exposed to high $\mathrm{K}^{+}$solution (78.3 mM NaCl, $51.5 \mathrm{mM} \mathrm{KCl}, 2.6 \mathrm{mM} \mathrm{CaCl}_{2}, 1.2 \mathrm{mM} \mathrm{MgSO}_{4}$, $5.6 \mathrm{mM}$ glucose, $25 \mathrm{mM}$ HEPES, $1.0 \mathrm{mM}$ ascorbic acid, $3 \%$ NHS, $\mathrm{pH}$ 7.3). After $30 \mathrm{~s}$, this solution was recovered for liquid scintillation spectrometry. To assess the cellular content of radioactivity, the cells were removed from the plate by trituration in $1.5 \mathrm{ml}$ of PBS (to which was added 2 mM EDTA and $0.5 \%$ Triton X-100) and retained for liquid scintillation spectrometry. Radioactive samples were solubilized in $10 \mathrm{ml}$ of scintillation cocktail (ACS or ScintiVerse $\mathrm{BD}$ ), and counted (Beckman LS 6500). Results for $\left[{ }^{3} \mathrm{H}\right]-\mathrm{DA}$ release are expressed as a percentage of the total cellular store of radioactivity as follows: ((released $\mathrm{cpm}) /$ total cellular cpm $) \times 100 \%$. Release experiments for cells treated with lithium used $\left[{ }^{3} \mathrm{H}\right]-\mathrm{DA}(1.0 \mathrm{mCi} / \mathrm{mmol})$ purchased from ICN Biomedicals, Inc. (for the valproate experiments the 
${ }^{3} \mathrm{H}$-DA was $1 \mathrm{mCi} / \mathrm{mmol}$, and was from Amersham Biosciences), and used an earlier passage of PC12 cells than in the valproate experiments. Three separate release experiments were performed with 3-4 plates of control (untreated) cells and 3-4 plates of treated cells (lithium or valproate). The data are for a total of 11 controls and 11 treated samples in each group. Students $t$-test was used to assess significance, ${ }^{*} p<0.05$.

\section{RESULTS}

In undifferentiated PC12 cells, neither lithium nor valproate produced a significant change in the expression of immunoreactive CSP, VAChT, VMAT1, SNAP-25, or SY (Table 1). These observations confirm and extend prior work (Cordeiro et al, 2000a, b), which indicated that lithium had no significant effect on the expression of CSP, SY, or SNAP-25 in undifferentiated PC12 cells. However, previously, we reported (Cordeiro et al, 2000b) that mRNA for VMAT1 and secretogranin, both of which are predominantly dense core vesicle proteins, decline in undifferentiated PC12 cells exposed to lithium. The absence of a change in VMAT1 at the protein level (Table 1) may reflect relatively slow turnover of this protein.

In NGF-differentiated PC12 cells, lithium and valproate independently led to an increase in the mRNA for CSP and VMAT1 (Figure 1a and b). Relative to untreated cells, CSP mRNA increased significantly in cells exposed to lithium $(293 \pm 52 \%, p<0.01)$ or valproate $(186 \pm 35 \%, p<0.05)$. Concomitantly, VMAT1 mRNA increased in response to these same drugs to $278 \pm 43$ and $174 \pm 30 \%$ (\% control, $p<0.05$ ), respectively. However, the expression of SY mRNA, which encodes a protein that is preferentially associated with SSV, was not significantly changed by these drug treatments (Figure 1a).

To determine whether the observed changes in mRNA (Figure $1 \mathrm{a}$ and $\mathrm{b}$ ) correlated with changes at the protein level, we assessed CSP, VMAT1, VAChT, SY, and SNAP-25 immunoreactivity in control-, lithium-, and valproatetreated cells. As documented in Figure 2a, immunoreactivity for VAChT, SY, and SNAP-25 did not change in response to these drugs. However, the levels of CSP and VMAT1 immunoreactivity increased during exposure to lithium or valproate (Figure 2a). Quantitative analysis revealed that SNAP-25, SY, and VAChT immunoreactivities remained between 90 and 105\% $(p>0.05)$ of control in cells treated with these drugs. Independently, CSP immunoreactivity increased to $173 \pm 17$ and $196 \pm 39 \%$ of control $(p<0.05)$ in cells treated with valproate or lithium (Figure $2 b$ ), while VMAT1 immunoreactivity concurrently increased to $140 \pm 15$ and $191 \pm 30 \%(p<0.05)$ of control, respectively
(Figure 2b). Although the effects of lithium tend to be quantitatively greater than those of valproate, the increase of CSP and VMAT1 expression (Figures 1 and 2), and the lack of change of SY, SNAP-25, and VAChT expressions point toward a common mechanism of action of these drugs.
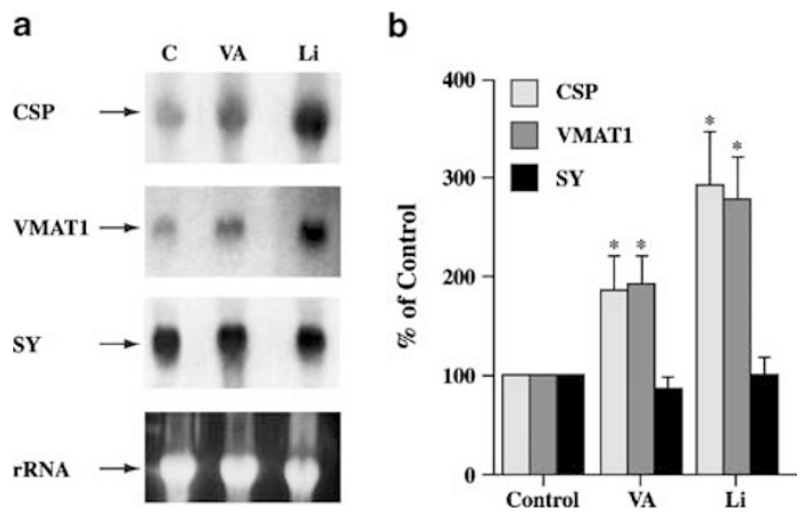

Figure I Impact of mood stabilizers on selected $\mathrm{PCI} 2$ cell mRNAs. NGF-differentiated PCI 2 cells were used for Northern analysis of specific mRNAs after treatment with valproate (I mM) or lithium (I mM) for $48 \mathrm{~h}$. (a) Representative northern blots of CSP, VMATI, and SY mRNA from cells treated with valproate (VA) or lithium (Li). (b) Densitometric analysis of CSP, VMATI, and SY mRNA content of $\mathrm{PCI} 2$ cells. Results are expressed as a percentage of untreated control (100\%) and presented as mean \pm SEM (error bars) from three or four independent experiments. *p $<0.05$.
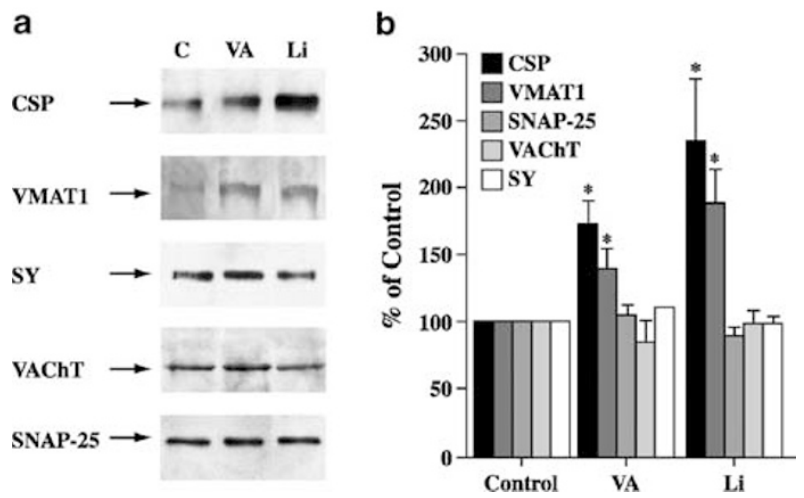

Figure 2 Immunoblot assessment of the expression of selected proteins in NGF-differentiated $\mathrm{PCI} 2$ cells. Using the same drug concentrations of Figure I, immunobolt assays were performed $48 \mathrm{~h}$ after treatment of cells with valproate or lithium. (a) Representative immunoblots of CSP, SNAP25, SY, VAChT, and VMATI. (b) Relative CSP, SNAP-25, SY, VAChT, and VMATI content. Results are expressed as a percentage of untreated control (100\%) and presented as mean \pm SEM (error bars) from four to seven independent experiments. $* p<0.05$.

Table I Summary of Protein Content of Undifferentiated PCI2 Cells Treated with Valproate or Lithium for $48 \mathrm{~h}$

\begin{tabular}{lccccc}
\hline & $\begin{array}{c}\text { CSP } \\
\text { (\%change } \pm \text { SE) }\end{array}$ & $\begin{array}{c}\text { SNAP25 } \\
\text { (\%change } \pm \text { SE) }\end{array}$ & $\begin{array}{c}\text { VMAT } \\
\text { (\%change } \pm \text { SE) }\end{array}$ & $\begin{array}{c}\text { VAChT } \\
\text { (\%change } \pm \text { SE) }\end{array}$ & $\begin{array}{c}\text { (\%change } \pm \text { SE) } \\
\text { Valproate }\end{array}$ \\
\hline Lithium & $107 \pm 5$ & $102 \pm 11$ & $116 \pm 17$ & $63 \pm 16$ & $119 \pm 17$ \\
\hline
\end{tabular}

Results are normalized to untreated cells at 100\%, p>0.05. 


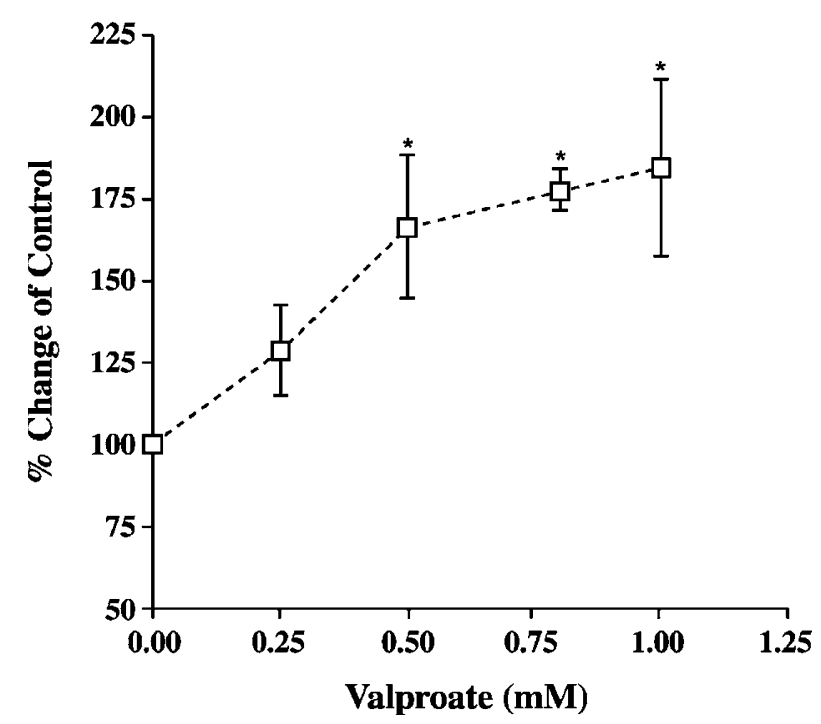

Figure 3 Expression of immunoreactive CSP as a function of valproate concentration. NGF-differentiated $\mathrm{PCl} 2$ cells were treated with the indicated concentrations of valproate for $48 \mathrm{~h}$ and extracts were submitted to immunoblot analysis for CSP. Densitometric results are normalized to untreated control cells (100\%). Data are results of three separate experiments. ${ }^{*} p<0.05$.

In the preceding experiments (Table 1, Figures 1 and 2), valproate was used at $1 \mathrm{mM}$, a concentration that exceeds the range of therapeutically relevant serum concentrations (up to $0.6 \mathrm{mM}$ ) in man. To ascertain whether valproate is active at lower concentrations, we evaluated its impact on the expression of CSP in NGF-differentiated PC12 cells. Results in Figure 3 indicate that valproate at $0.5-1 \mathrm{mM}$ leads to a significant increase of CSP immunoreactivity, whereas $0.25 \mathrm{mM}$ valproate does not significantly affect CSP content within $48 \mathrm{~h}$.

The changes of protein expression documented in Figure 2 raise the possibility that secretory dynamics are altered in PC12 cells treated with lithium or valproate. To address this possibility, we measured the spontaneous and depolarization-dependent release of radioactivity from cells loaded with $\left[{ }^{3} \mathrm{H}\right]$-DA. The results in Figure 4 indicate that there is no significant change in the rate of spontaneous secretion in cells exposed either to lithium or valproate. However, under depolarizing conditions $\left(51.5 \mathrm{mM} \mathrm{K}^{+}\right.$for $\left.30 \mathrm{~s}\right)$, cells treated with either lithium or valproate exhibited approximately a $30 \%$ increase (significant at $p<0.05$ in both instances) in the amount of radioactivity released. Thus, the increases of CSP and VMAT1 expression are correlated with changes in the secretory behavior of these cells.

\section{DISCUSSION}

In principle, the therapeutic actions of lithium and valproate in manic-depressive disorders could arise from independent pathways that have similar impacts on mood stabilization. However, a more common inference has been that these structurally dissimilar agents converge at some level to produce their therapeutic effects (Post et al, 1992). In support of this latter position are the observations (see Introduction) documenting the overlapping actions of lithium and valproate in a number of signaling pathways.
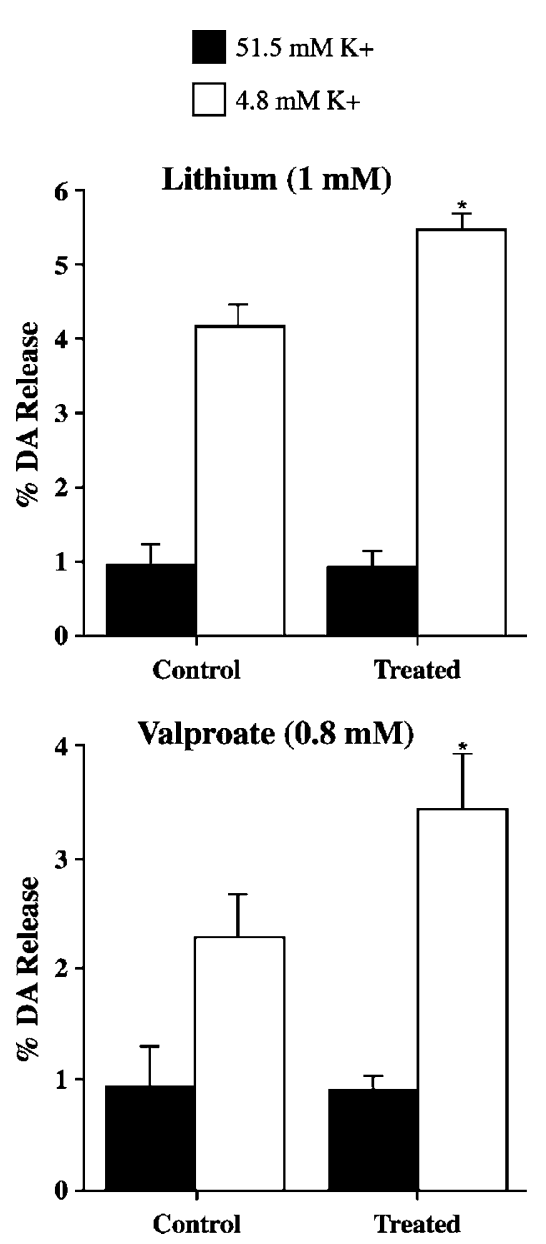

Figure 4 Spontaneous and depolarization-dependent secretion from $\mathrm{PCI} 2$ cells loaded with $\left[{ }^{3} \mathrm{H}\right] \mathrm{DA}$. Results reflect the amount of radioactivity released from cells during a $30 \mathrm{~s}$ collection period in normal or high $\mathrm{K}^{+}$ buffer relative to the total cellular content of radioactivity at the beginning of the two collection periods (normalized to 100\%). There was no significant difference in uptake of radioactive dopamine between control or drug-treated cells. Results are the mean (+SEM) of data from I I separate plates for each condition. The lithium experiments used an earlier passage of $\mathrm{PCl} 2$ cells. ${ }^{*} p<0.05$ compared with high $\mathrm{K}^{+}$-evoked secretion in controls.

The current study provides additional support for the hypothesis that lithium and valproate have convergent effects on specific aspects of cell function. Thus, these drugs increased the level of mRNA and the cellular content of proteins (CSP and VMAT1) involved in the function of LDCV. These effects were detected in NGF-differentiated PC12 cells, but not in undifferentiated cells. Since NGFdifferentiated PC12 cells acquire a more neuron-like phenotype in the differentiated state (Tischler and Greene, 1975; Dichter et al, 1977; Schubert et al, 1977), these data imply that there may be environmental factors that dictate the sensitivity of specific cells or cell populations to these drugs. Moreover, lithium and valproate augmented the expression of VMAT1 which is largely confined to LDCV, and we detected no effect of these drugs on the expression of proteins (VAChT or SY), which are predominantly associated with SSV (Liu et al, 1994; Liu and Edwards, 1997). Likewise, the expression of the presynaptic plasma membrane protein SNAP-25 was unaltered by these drugs. These data indicate that there is considerable specificity in 
the target genes that are regulated by lithium and valproate, and that they share a requirement for PC12 cells to be in an NGF-differentiated (and more neuron-like) state for these effects to be observed.

An interesting issue that is not resolved by our results is whether the increased cellular content of csp and VMAT1 is associated with a higher density of these proteins per LDCV, or whether there are more LDVCs per cell (with essentially the same number of csp and VMAT1 molecules per LDCV). Additional work will be needed to clarify this situation. However, our prior work does suggest that the effect of lithium (and we infer that this is also likely to be the case for valproate) on cellular mRNA and protein content involves enhanced transcription of specific target genes. This is because actinomycin $\mathrm{D}$ completely blocked the increase of csp in NGF-differentiated cells exposed to lithium (Cordeiro et al, 2000a). Nevertheless, we cannot exclude the possibility that lithium also has subtle effects on mRNA or protein stability.

Importantly, we also observed that both lithium and valproate influence the regulated secretory behavior of NGF-differentiated PC12 cells. Although spontaneous secretion was unaffected by these drugs, both agents significantly enhanced the depolarization-dependent release of radioactivity from cells preloaded with $\left[{ }^{3} \mathrm{H}\right]-\mathrm{DA}$. Although it remains to be established whether the reported changes of LDCV protein expression contribute mechanistically to this change in the regulated secretory behavior of these cells, there is ample evidence from other groups that lithium alters the content and secretion of monoamines and selected neuropeptides, which are stored in and released from LDCV (Hesketh et al, 1978; Treiser et al, 1981; Staunton et al, 1982; Ebstein et al, 1983; Hong et al, 1983; Mitsushio et al, 1988; Sivam et al, 1988, 1989; Mathé et al, 1990; Husum et al, 2000; Shiah and Yatham, 2000). And, as observed in the current experiments, in the majority of these cited examples, the effect of lithium was to increase the content or secretion of the neurotransmitter or neuromodulator. However, because we have also observed downregulation of transcripts for VMAT1 and secretogranin in undifferentiated PC-12 cells exposed to lithium (Cordeiro et al, $2000 \mathrm{~b})$, this cation clearly exerts pleiotropic effects on specific gene products. In this same context, several groups have reported that valproate alters the level of dopamine or serotonin in discrete brain areas (Biggs et al, 1992; Mitsikostas et al, 1993; Baf et al, 1994; Loscher and Honack, 1996; Vriend and Alexiuk, 1996; Ichikawa and Meltzer, 1999). Given the important role of biogenic amines in mood and behavior (Baldessarini, 1990), it will be of interest to ascertain whether changes in the expression of LDCV proteins contribute to the actions of mood stabilizers, both in vitro and in vivo. (In this context, recent in situ hybridization studies have documented significant changes of VMAT2 mRNA (Cordeiro et al, 2002) and csp mRNA (Corderio et al, 2003) in discrete areas of the brain of rats fed a lithium-supplemented diet.) Thus, the current report provides a potential link between studies showing alterations in monoamines (and some neuropeptides) in response to lithium or valproate, and changes in proteins that are essential components of LDCV in the brain.

Another issue of considerable importance is to identify the mechanism(s) by which lithium and valproate influence the expression of CSP and VMAT1. Given the structural dissimilarity of these two drugs, it is unlikely that they interact with the same proximal target(s). A more plausible hypothesis is that their actions converge at the transcriptional level to produce overlapping changes in gene expression. Thus, a better understanding of the regulatory elements that control the expression of genes sensitive to lithium or valproate should aid in clarifying the signaling pathways that underlie these changes of gene expression.

\section{ACKNOWLEDGEMENTS}

We are grateful to Dr E Schweitzer for the PC12 cells and comments, and Dr S Gambhir for analytical equipment. This work was supported by NIH Grant NS31934 (JAU) and an Ahmanson Neurobiology Post-doctoral Fellowship (MLC).

\section{REFERENCES}

Baf MH, Subhash MN, Lakshmana KM, Rao BS (1994). Sodium valproate induced alterations in monoamine levels in different regions of the rat brain. Neurochem Int 24: 67-72.

Baldessarini RJ (1990). Drugs and the treatment of psychiatric disorders. In: Gilman AG, Rall TW, Nies AS, Taylor P (eds). Goodman and Gilman's The Pharmacological Basis of Therapeutics, 8th edn. Pergamon Press: Oxford. pp 383-435.

Biggs CS, Pearce BR, Fowler LJ, Whitton PS (1992). Regional effects of sodium valproate on extracellular concentrations of 5hydroxytryptamine, dopamine, and their metabolites in the rat brain: an in vivo microdialysis study. J Neurochem 59: 1702-1708.

Bradford MM (1976). A rapid and sensitive method for the quantitation of microgram quantities of protein utilizing the principle of protein-dye binding. Anal Biochem 72: 248-254.

Chen B, Wang JF, Hill BC, Young LT (1999). Lithium and valproate differentially regulate brain regional expression of phosphorylated CREB and c-Fos. Brain Res Mol Brain Res 70: 45-53.

Chen G, Yuan PX, Jiang YM, Huang LD, Manji HK (1998). Lithium increases tyrosine hydroxylase levels both in vivo and in vitro. J Neurochem 70: 1768-1771.

Compton MT, Nemeroff CB (2000). The treatment of bipolar depression. J Clin Psychiatry 61(Suppl 9): 57-67.

Cordeiro ML, Gundersen CB, Umbach JA (2002). Lithium ions modulate the expression of VMAT2 in rat brain. Brain Res 953: 189-194.

Corderio ML, Gundersen CB, Umbach JA (2003). Dietary lithium induces regional increases of mRNA encoding cysteine string protein in rat brain. $J$ Neurosci Res (in press).

Cordeiro ML, Umbach JA, Gundersen CB (2000a). Lithium ions enhance cysteine string protein gene expression in vivo and in vitro. J Neurochem 74: 2365-2372.

Cordeiro ML, Umbach JA, Gundersen CB (2000b). Lithium ions up-regulate mRNAs encoding dense-core vesicle proteins in nerve growth factor-differentiated PC12 cells. J Neurochem 75: 2622-2625.

Dichter MA, Tischler AS, Greene LA (1977). Nerve growth factorinduced increase in electrical excitability and acetylcholine sensitivity of a rat pheochromocytoma cell line. Nature 268: 501-504.

Ebstein RP, Lerer B, Shlaufman M, Belmaker RH (1983). The effect of repeated electroconvulsive shock treatment and chronic lithium feeding on the release of norepinephrine from rat cortical vesicular preparations. Cell Mol Neurobiol 3: 191-201. 
Goodwin FK, Jamison KR (1990). Manic-depressive Illness. Oxford University Press, Inc.: New York.

Greene LA, Rein G (1977). Release of $\left[{ }^{3} \mathrm{H}\right]$ Norepinephrine from a clonal line of Pheochromocytoma (PC12) by nicotinic cholinergic stimulation. Brain Res 138: 521-528.

Hesketh JE, Nicolaou NM, Arbuthnott GW, Wright AK (1978). The effect of chronic lithium administration on dopamine metabolism in rat striatum. Psychopharmacology 56: 163-166.

Hong JS, Tilson HA, Yoshikawa K (1983). Effects of lithium and haloperidol administration on the rat brain levels of substance $\mathrm{P}$. J Pharmacol Exp Ther 224: 590-593.

Husum H, Mikkelsen JD, Hogg S, Mathe AA, Mork A (2000). Involvement of hippocampal neuropeptide $\mathrm{Y}$ in mediating the chronic actions of lithium, electroconvulsive stimulation and citalopram. Neuropharmacology 39: 1463-1473.

Ichikawa J, Meltzer HY (1999). Valproate and carbamazepine increase prefrontal dopamine release by 5 -HT1A receptor activation. Eur J Pharmacol 380: R1-R3.

Lenox RH, McNamara RK, Watterson JM, Watson DG (1996). Myristoylated alanine-rich C kinase substrate (MARCKS): a molecular target for the therapeutic action of mood stabilizers in the brain? J Clin Psychiatry 57(Suppl 13): 23-31; discussion 32-23.

Liu Y, Edwards RH (1997). Differential localization of vesicular acetylcholine and monoamine transporters in PC12 cells but not CHO cells. J Cell Biol 139: 907-916.

Liu Y, Schweitzer ES, Nirenberg MJ, Pickel VM, Evans CJ, Edwards RH (1994). Preferential localization of a vesicular monoamine transporter to dense core vesicles in PC12 cells. J Cell Biol 127: 1419-1433.

Loscher W, Honack D (1996). Valproate and its major metabolite E-2-en-valproate induce different effects on behaviour and brain monoamine metabolism in rats. Eur J Pharmacol 299: 61-67.

Mathé AA, Jousisto-Hanson J, Stenfors C, Theodorsson E (1990). Effect of lithium on tachykinins, calcitonin gene-related peptide, and neuropeptide $\mathrm{Y}$ in rat brain. J Neurosci Res 26: 233-237.

McElroy SL, Keck Jr PE (2000). Pharmacologic agents for the treatment of acute bipolar mania. Biol Psychiatry 48: 539-557.

Mitsikostas D, Sfikakis A, Papadopoulou-Daifoti Z, Varonos D (1993). The effects of valproate in brain monoamines of juvenile rats after stress. Prog Neuropsychopharmacol Biol Psychiatry 17: 295-310.

Mitsushio H, Takashima M, Mataga N, Toru M (1988). Effects of chronic treatment with trihexyphenidyl and carbamazepine alone or in combination with haloperidol on substance $\mathrm{P}$ content in rat brain: a possible implication of substance $\mathrm{P}$ in affective disorders. J Pharmacol Exp Ther 245: 982-989.

Nemeroff CB (2000). An ever-increasing pharmacopoeia for the management of patients with bipolar disorder. J Clin Psychiatry 61(Suppl 13): 19-25.

Ozaki N, Chuang DM (1997). Lithium increases transcription factor binding to AP-1 and cyclic AMP-responsive element in cultured neurons and rat brain. J Neurochem 69: 2336-2344.
Post RM, Weiss SR, Chuang DM (1992). Mechanisms of action of anticonvulsants in affective disorders: comparisons with lithium. J Clin Psychopharmacol 12: 23S-35S.

Sands SA, Guerra V, Morilak DA (2000). Changes in tyrosine hydroxylase mRNA expression in the rat locus coeruleus following acute or chronic treatment with valproic acid. Neuropsychopharmacology 22: 27-35.

Schou M (1997). Forty years of lithium treatment. Arch Gen Psychiatry 54: 9-15.

Schubert D, Heinemann S, Kidokoro Y (1977). Cholinergic metabolism and synapse formation by a rat nerve cell line. Proc Natl Acad Sci USA 74: 2579-2583.

Shiah IS, Yatham LN (2000). Serotonin in mania and in the mechanism of action of mood stabilizers: a review of clinical studies. Bipolar Disord 2: 77-92.

Sivam SP, Krause JE, Takeuchi K, Li S, McGinty JF, Hong JS (1989). Lithium increases rat striatal beta- and gamma-preprotachykinin messenger RNAs. J Pharmacol Exp Ther 248: 1297-1301.

Sivam SP, Takeuchi K, Li S, Douglass J, Civelli O, Calvetta L et al (1988). Lithium increases dynorphin $\mathrm{A}(1-8)$ and prodynorphin mRNA levels in the basal ganglia of rats. Brain Res 427: 155-163.

Staunton DA, Deyo SN, Shoemaker WJ, Ettenberg A, Bloom FE (1982). Effects of chronic lithium on enkephalin systems and pain responsiveness. Life Sci 31: 1837-1840.

Tischler AS, Greene LA (1975). Nerve growth factor-induced process formation by cultured rat pheochromocytoma cells. Nature 258: 341-342.

Treiser SL, Cascio CS, O'Donohue TL, Jacobowitz DM, Kellar KJ (1981). Lithium increases serotonin release and decreases serotonin receptors in the hippocampus. Science 213: 1529-1531.

Vriend JP, Alexiuk NA (1996). Effects of valproate on amino acid and monoamine concentrations in striatum of audiogenic seizure-prone Balb/c mice. Mol Chem Neuropathol 27: 307-324.

Watson DG, Watterson JM, Lenox RH (1998). Sodium valproate down-regulates the myristoylated alanine-rich $\mathrm{C}$ kinase substrate (MARCKS) in immortalized hippocampal cells: a property of protein kinase C-mediated mood stabilizers. J Pharmacol Exp Ther 285: 307-316.

Wessel D, Flugge UI (1984). A method for the quantitative recovery of protein in dilute solution in the presence of detergents and lipids. Anal Biochem 138: 141-143.

Williams RS, Cheng L, Mudge AW, Harwood AJ (2002). A common mechanism of action for three mood-stabilizing drugs. Nature 417: 292-295.

Yuan P, Chen G, Manji HK (1999). Lithium activates the c-Jun $\mathrm{NH}_{2}$-terminal kinases in vitro and in the CNS in vivo. J Neurochem 73: 2299-2309.

Yuan PX, Chen G, Huang LD, Manji HK (1998). Lithium stimulates gene expression through the AP-1 transcription factor pathway. Brain Res Mol Brain Res 58: 225-230.

Zigova T, Willing AE, Tedesco EM, Borlongan CV, Saporta S, Snable GL et al (1999). Lithium chloride induces the expression of tyrosine hydroxylase in hNT neurons. Exp Neurol 157: 251-258. 